\title{
Breeding prerequisites for Ortolan Bunting Emberiza hortulana in Swedish farmland, with special focus on foraging
}

\section{Häckningsförutsättningar för ortolansparv i svenskt jordbruk, med särskilt fokus på födosöket}

\author{
Jan Sondell', Carles Durà ${ }^{2}$ \& Magnus Persson ${ }^{3}$ \\ 1 Rulleuddsvägen 10, 17851 Ekerö, Sweden | jan.sondell@telia.com²43580 Deltebre, Spain | carles7292@gmail.com \\ ${ }^{3}$ Husön, 71592 St Mellösa, Sweden | humlapersson@gmail.com
}

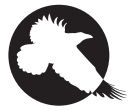

ORTOLAN BUNTINGS are rapidly decreasing in Sweden, mainly due to changes in agricultural practices. Landscape simplification due to the removal of semi-natural elements leads to a lack of breeding habitats. Furthermore, due to intensive artificial fertiliser applications and advanced agricultural equipment and technology, crops grow taller and denser than 50 years ago. In Kvismaren, south central Sweden, Ortolan Buntings have been studied since 2009. Here, we focus on one question: what defines a good foraging microhabitat? In 2017, five nests were located, and we made 271 observations of feeding parents. Average foraging distance at different nests varied between 47 and $114 \mathrm{~m}$. About $70 \%$ of the foraging activities took place within crop fields. Ortolans mainly utilized unsown rows, that tractors later follow during e.g. spraying, and patchy parts of standing crops. Invertebrates extracted from those areas looked dark, suggestive of ground-dwelling species. Our management recommendation to leave two unsown rows (amounting to $37.5 \mathrm{~cm}$ in width) to create better microhabitats can be achieved by most farmers, but might not be sufficient to maintain the population. No conservation efforts of a reliable positive effect are known to date.

Keywords: agriculture | conservation | passerine bird | agro-environmental solutions

\section{Introduction}

Ortolan Buntings Emberiza hortulana have decreased in Western Europe for many decades (e.g. Stolt 1993, Vepsäläinen et al. 2005, Menz \& Arlettaz 2011, Naturvårdsverket 2017) including Sweden (Ottvall et al.
2008, Green et al. 2018). Jiguet et al. (2016a) reviewed population trends since the beginning of the millennium across 39 European countries, and found that while the populations were stable or fluctuating in six 
countries and increasing in two (Germany and Serbia), 14 out of 15 countries with decreasing population sizes were located in Northern Europe. Particularly in southern and central Sweden, Ortolan Buntings (henceforth referred to as ortolans) have decreased rapidly during the last decades (Ottosson et al. 2012, Green et al. 2018), and today less than 100 pairs remain in Sweden south of Limes Norrlandicus (judged from Artportalen and own observations).

Because of the alarming situation BirdLife Sweden started a project in 2011, to identify reasons for the ortolan decline and to introduce potential management actions. The Swedish Environmental Protection Agency created a management plan for the species, which was resolved for the period 2017-2021 in April 2017 (Naturvårdsverket 2017).

The reasons for the rapid decline of ortolans were unclear for a long time (Menz \& Arlettaz 2011). Changes in a variety of breeding habitats (particularly the agricultural areas; Wretenberg et al. 2007), environmental toxins, poaching in France (Jiguet et al. 2016b), and generally high mortality during migration and in the wintering areas are some of the possible explanations (Vepsäläinen et al. 2005, Menz \& Arlettaz 2011, Naturvårdsverket 2017). In Finland, a population crash in the early 1990 os was specifically "associated with the amount of small-scale environmental heterogeneity and with agricultural practices" (Vepsäläinen et al. 2005).

Ortolans are today present in the Nordic countries in a range of different breeding environments: farmland, forest clear-cuts in the northern parts, wild fire zones, peat bogs, energy forest, and gravel extraction quarries (Dale 2000, Dale et al. 2002, Berg 2008, Ottvall et al.
2008, Sondell et al. 2014), but also in industrial areas including runways and railroads (Artportalen). This diverse habitat use has confounded attempts to characterize preferred or optimal breeding and foraging habitat for the species. In this study, we will focus on the use of farmland habitat for breeding and foraging, since changes in agricultural practices and policies have affected the ortolans and other Swedish farmland birds negatively (Wretenberg et al. 2007).

Fifty years ago the species was fairly common in Kvismaren, a valley in south central Sweden containing wetland and farmland areas: Runesson \& Jönsson (1987) found around 50 territories in four census areas, which only represented a subset of the valley. By 2012, the ortolan had decreased to 9-10 pairs in the whole valley (Sondell 2013), while only four nests were found in 2016, and five nests in 2017 (this study). See Appendix 1 for local population trends of ortolans and yellowhammers E. citrinella. Intensive monitoring of the ortolans in the Sörön area of Kvismaren started in 2009 (Sondell et al. 2011), coinciding with the first vegetation clearances to improve the habitat of the breeding copses (Sondell et al. 2011). During 2016-2017 all nests have been located and we have confirmed that most nests have succeeded to produce fledglings. Recruitment, however, is weak. In 2016 no new individuals appeared in Kvismaren.

When studying the last ortolans of Switzerland, Menz et al. (2009) found that there was no general lack of food. The ortolans were forced to use the best of a poor set of options because food availability (and / or cover of it) was dependent of habitat selection rather than food abundance. Breeding ortolans mainly forage on the ground and require bare soil for searching

\section{Definitions}

As unsown ground or unsown rows is crucial for the foraging of ortolans in this study we will define some concepts connected to this:

UNSOWN Rows - normally two rows are left unsown per tractor wheel to avoid damages from the tractor to the growing crop later in the vegetation period, during e.g. spraying.

UNSOWN TRACTOR TRACKS - later made by the farm tractor when following the prepared unsown rows. In the present study we always discuss pairs of tracks, approximately $2 \mathrm{~m}$ apart, corresponding to the tractor wheel distance.

TRAMLINES - this word is often used when discussing unsown rows or tractor tracks in crop fields. It has no equivalence in Swedish and we chose to use the terms unsown rows and unsown tractor tracks throughout this paper. 


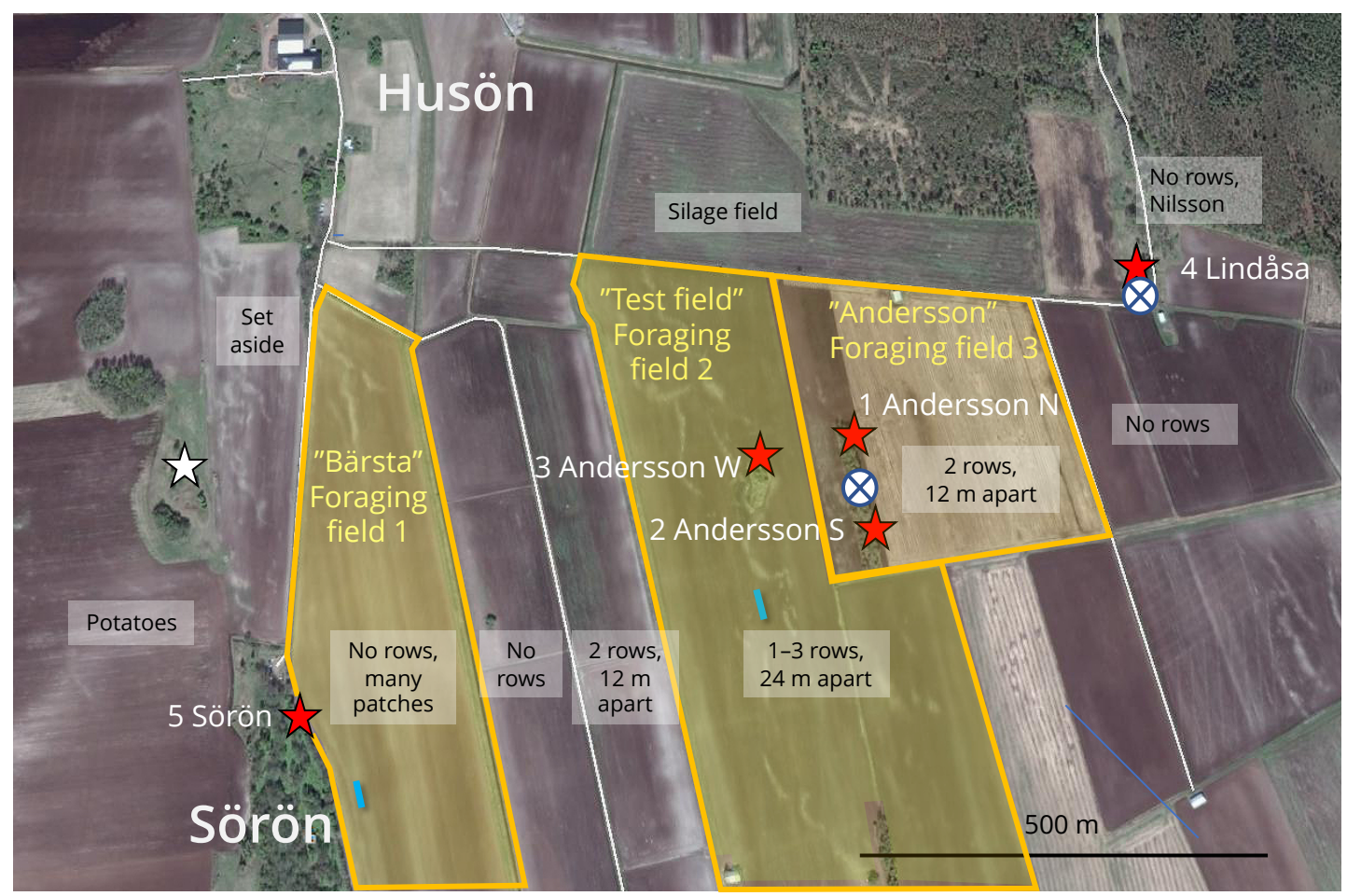

FIGURE 1. Study area in the north-eastern part of the Kvismaren valley, with field characteristics, nest locations, and field foraging allocation. Field characteristics in terms of unsown rows per tractor wheel track are stated with black font in lightly shaded boxes. The three main foraging fields are named in yellow font and delimited by orange borders. Fields with (i) no, (ii) 2, and (iii) alternating 1, 2, and 3 unsown rows in tractor wheel tracks are all spring-sown crops (wheat). Note that the unsown tractor tracks are at different distances, 12 or $24 \mathrm{~m}$, and that there are two "lark plots" (light blue; see text). Red stars indicate active nests (names in white) for Ortolan Buntings Emberiza hortulana in 2017 and the white star an unpaired male. Two oat feeders are indicated with blue crosses. Image source: Google Maps.

- Studieområde i nordöstra Kvismardalen med fältegenskaper, boplatser och födosöksfrekvens. De tre huvudsakliga "födosöksfälten" är markerade med gul text och avgränsade med orange linjer. Fält med inga, 2 och 1, 2 resp. 3 rader är alla vårvetefält. Notera att de osådda raderna i traktorspåren är på olika avstånd (12 resp. 24 m) och att det finns två lärkrutor (ljusblå). Röda stjärnor indikerar aktiva bon (namn i vitt) för ortolansparv Emberiza hortulana och en vit stjärna en oparad hanne. Två matare med havre markeras med blå kryss. Bildkälla: Google Maps.

for prey (e.g. Menz et al. 2009, Menz \& Arlettaz 2011, Morelli 2012, Brambilla et al. 2016). It is known that ortolans also eat green larvae found in tree crowns (Stolt 1974), as well as seeds - mainly oats in Sweden (JS, pers. obs.). Menz et al. (2009) determined that without open soil in fairly small patches, the food (usually dark invertebrates) is difficult for ortolans to find and extract. We thus suggest that a key factor for the decrease of Ortolan Buntings all over Europe may be that the foraging prerequisites are not good enough, hence cannot support a reproductive output that maintains the population size.

With the current agricultural practices most farmland in Kvismaren is covered with green vegetation by May, and we postulate that the main reason for the decreased ortolan population is the lack of bare soil in the agricultural landscape between May and early July. In this paper, we try to understand if changes in crop sowing methods can be linked to breeding performance, as measured by adult foraging preferences. Since lack of foraging opportunities may be limiting the population, knowledge of preferred habitat types and vegetation structure where ortolans forage can inform management provisions to counteract recent ortolan population declines in farmland areas.

Our objective was to find out where the ortolans prefer to forage, with respect to the kind of ground coverage, type of crop, crop density, and proximity to taller 
crop edge vegetation. To do so, we aimed at observing foraging trips of the breeding adults to assess (a) what foraging habitats they used, specifically focusing on the impact of sowing rows left unsown for the tractor wheels in crop fields, and, if possible, (b) which type of prey they returned to the nest. We provide some insights into foraging requirements of ortolans, along with management recommendations to aid provision of the most frequently selected foraging habitats at remaining farmland breeding sites in Sweden.

\section{Methods}

\section{STUDY AREA AND SPECIES}

Kvismaren $\left(59^{\circ} 11^{\prime} \mathrm{N}, 15^{\circ} 24^{\prime} \mathrm{E}\right)$ is a shallow valley comprising 10,000 hectares $(20 \times 5 \mathrm{~km})$. It is drained by a wide canal leading to Lake Hjälmaren. Almost 90\% of the area consists of farmland with large fields; many of them on soil with high organic content. Farming in the area is dominated by cereal production, mainly by fields that are sown in spring, but also fields of potatoes and carrots. Crops sown during autumn are uncommon, and only occur on clay soils. Grass for silage production is also grown in some parts of the valley. Although Ottosson et al. (2012) estimate 5-15 pairs to breed in Östergötland County, the past five years have seen no breeding birds there (Artportalen), and thus the Kvismaren farmlands (Figure 1) constitute the southernmost area of breeding ortolans in Sweden. Ortolans usually arrive from West Africa (Selstam et al. 2015) to the breeding grounds at Kvismaren in the first half of May. They typically sing from tree copses in the agricultural landscape and place their nest in natural grass at the border of the copses or in the crop fields nearby (pers. obs.). Females are sometimes regarded less numerous than males (Steifetten \& Dale 2006), however, they might be under-recorded due to more cryptic behaviour, despite being easier to discover during the nest building period. During egg laying and incubation both sexes are harder to detect, as the male in most cases only sings a "short song" i.e. truncating after the first part of the strophe. After hatching, presence of the pair becomes apparent again.

\section{DESIGN OF EXPERIMENTAL FIELD}

In order to assess the preference for size of patches of
TABLE 1. Data registered during the field observations of Ortolan Buntings Emberiza hortulana at Kvismaren 2017.

- Data som registrerades vid fältobservationerna av ortolansparv Emberiza hortulana vid Kvismaren 2017.

\begin{tabular}{ll}
\hline Data about foraging rounds & Data kring födosök \\
\hline Sex of the bird & Fågelns kön \\
Singing or resting place & Sång- eller viloplats \\
Nest area & Boområde \\
Observation place & Observationsplats \\
Direction of movement & Förflyttningsriktning \\
Perching site & Landningsplats \\
Feeding round no. & Födosök, nummer \\
Foraging area info: & Uppgifter födosöksområdet: \\
- type of crop & - typ av gröda \\
- no. of unsown rows & - antal osådda rader \\
- bare patches in crop & - bara fläckar i fältet \\
- uncultivated field borders & - obrukade fältkanter \\
- ditches & - diken \\
- canopy & - trädkronor \\
\hline
\end{tabular}

bare soil of foraging ortolans, we designed a test field near the breeding area (entitled Test field) in April 2017. As is standard for modern crop fields, the sowing machine left unsown rows every $24 \mathrm{~m}$ for subsequent spraying of pesticides and fertilizer. At that interval, in each wheel track one, two, and three sowing rows - corresponding to $25,37.5$, and $50 \mathrm{~cm}$ - were left unsown alternating across the field (Figures 1, 2). Our aim was to assess preference within the Test field as well as between the Test field and any other fields used for foraging.

\section{FORAGING OBSERVATIONS}

We undertook daily monitoring of the foraging trips of breeding ortolans at a study site located at Kvismaren (Figure 1) in 2017, with the aim of recording foraging locations and investigating whether certain crop sowing methods produced more attractive spring wheat crops for foraging than others. Some breeding data was collected, along with crop height and weed growth data and incidental observations of food items. All fields within the main study area were sown with spring wheat in April-May 2017.

Nests were located with a resolution accuracy of $\leq$ $25 \times 25 \mathrm{~m}$. Only two nests were visited, to avoid unnecessary disturbance, and one of those was only checked 


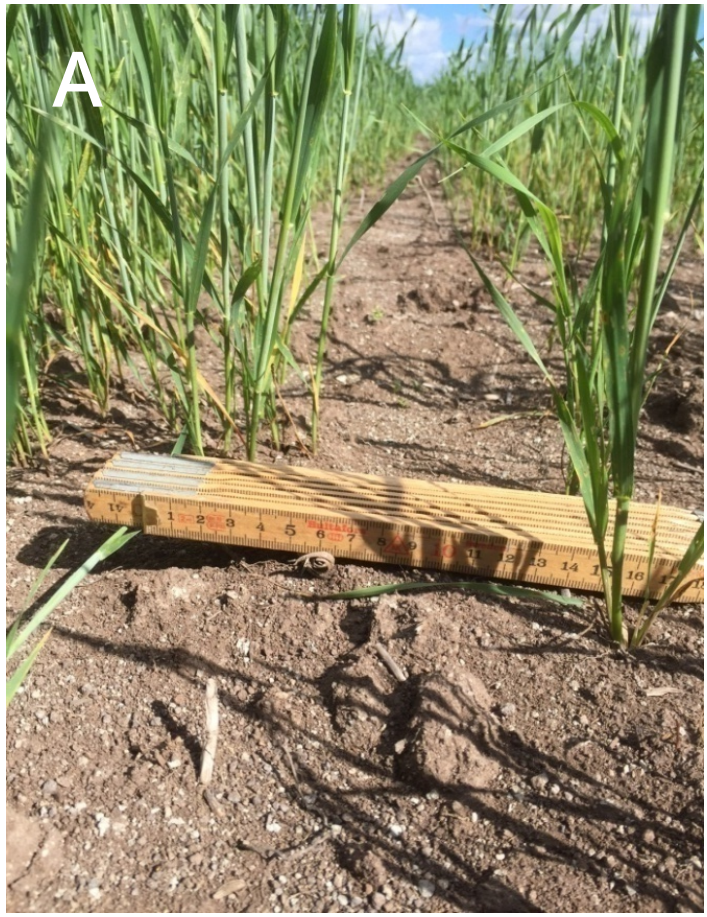

FIGURE 2. Comparison of space for wheel tracks with one (a) and three (b) unsown rows in the Test field on 27 June 2017. Photo: Magnus

- Jämförelse av traktorhjulspår med en (a) respektive tre (b) osådda rader 27 juni 2017 i Testfältet. Foto: Magnus Persson.

after fledging. Fledglings from the others were observed and counted or estimated after leaving the nest.

Observations were made according to Table 1 by two observer teams of one to three people during each morning between the 30 th of May and the 1oth of July. Based on the knowledge of the nest areas, weather, etc., the teams decided which nest to start to observe each day. As far as possible the observations were evenly scheduled. (Nest Andersson 3 was however found later that the others.) Nest activity was greatest during the morning and evening hours, thus we preferably made observations at these times. If the activity of a given nest was low, the focus might shift to another nest. Observation posts were chosen to overlook the primary nest area, but sometimes covered an additional nest as well. Outlooks were not predefined but the team members searched the best posts depending on wind and light conditions and distance to the actual nest. Even within a team different observers were sometimes located rather far from each other. We sometimes used cars (occasionally even driving off road in the fields) or

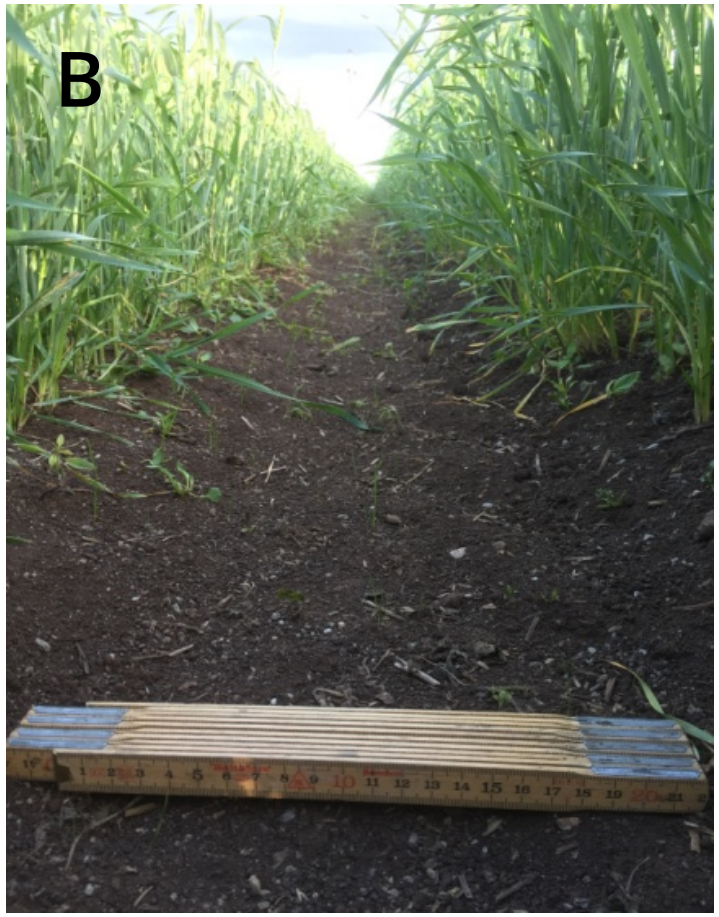

hunched down close to obstacles to minimise disturbance, and a permanent hunting tower was also used as observation point.

Ortolans flying to and from the nest were observed using binoculars and spotting scopes. A bird bringing food to the nest was followed also when leaving for the next trip. The main focus was on where birds landed after leaving the nest, as this was interpreted as the foraging location. If possible the bird was spotted again when lifting with a new load of food. Sometimes several consecutive foraging trips were possible to track, as many birds returned to the same area for foraging.

The teams, or sometimes people within a team, had continuous radio or cell phone communication when necessary. Sometimes the bird left a nest and flew far away, or behind an obstacle of sight, and the observer(s) lost contact. These trips were not included in any of the analyses, and represented only some $5 \%$ of the observations. Another difficulty was to identify the sex of the feeding bird. However, three males were colour ringed, which alleviated this problem. 
The movements and activities of the birds were registered as accurately as possible on maps printed from Google Maps displayed at an appropriate scale (see example in Appendix 2). All distances were the shortest way measured with the Google ruler tools. Assessing what food items the birds carried was often difficult, especially during the beginning of the foraging period, as the invertebrates at that time were very small. Google Maps were directly accessible on cell phones in the field, facilitating the determination of foraging positions and calculation of distances.

\section{Results}

\section{BREEDING RESULTS}

Ortolans were present only in the north-eastern part of the Kvismaren valley. The foraging of all nine breeding individuals was studied, and five nest areas were located (Figure 1). Nests 4 (Lindåsa) and 5 (Sörön) were situated in natural grass and involved a polygynous male (see Persson \& Sondell 2018). The remaining nests held socially monogamous pairs. The exact locations of nests 1 (Andersson $\mathrm{N}$ ) and 2 (Andersson $\mathrm{S}$ ) were unknown, but determined to $25 \times 25 \mathrm{~m}$ areas, and were possibly also placed in natural grass close to the crop fields. Nest 3 (Andersson W) was situated in spring wheat in the Test field and located after the youngsters were fledged. Diverse crop types and sowing patterns were present around nest sites, see Figure 1. For further data on the nests, see Table 2.

\section{FORAGING}

In total 271 successful foraging trips were registered between the 18 May and the 7 July, and the observations mainly regarded females. Before the chicks hatched, the feeding trips were infrequent but after hatching the parents at times brought food up to every 3-10 minutes. There was a tendency that ortolans returned to the place where they had found food during the previous foraging trip; hence a bird sometimes flew to the same foraging place several times (Table 3 ).

Only $18 \%$ of all foraging observed was outside the crop fields, and then mainly in natural grass, at oat feeders, and in the tree canopies (Table 3). Only one instance of successful hunting of insects in flight was observed. The majority of foraging happened on crop fields: the Andersson field with two unsown rows was the target for $41 \%$ of the foraging trips, and adding the Test field (foraging field 2 with one to three unsown rows) gives a total proportion of feeding on fields with unsown rows of $47 \%$, compared to $22 \%$ for other fields, of which the patchy Bärsta field makes up $17 \%$ (Table $3)$. Note that the foraging pattern differs markedly between parents of different nests (Table 3). Potential foraging trips where the observer lost contact with the bird (estimated to some 5\%) are not included.

It was very difficult to see what type of food the

TABLE 2. Description of Ortolan Bunting Emberiza hortulana nest environments at Kvismaren 2017.

- Beskrivning av bomiljöer för ortolansparv Emberiza hortulana vid Kvismaren 2017.

\begin{tabular}{|c|c|c|c|c|c|}
\hline $\begin{array}{l}\text { Name of nest } \\
\text { area } \\
\text { Boområdets } \\
\text { namn }\end{array}$ & $\begin{array}{l}\text { Number } \\
\text { of chicks } \\
\text { Antal } \\
\text { ungar }\end{array}$ & $\begin{array}{l}\text { Type of nest area } \\
\text { Typ av bomiljö }\end{array}$ & $\begin{array}{l}\text { Distance to } \\
\text { trees / bushes } \\
\text { Avstånd till } \\
\text { träd / buskar }\end{array}$ & $\begin{array}{l}\text { Dominant vegetation } \\
\text { around nest } \\
\text { Vegetation omkring } \\
\text { boet }\end{array}$ & $\begin{array}{l}\text { Approx. hatching date (basis for } \\
\text { assumption) } \\
\text { Ungefärlig kläckdag (underlag för } \\
\text { bedömning) }\end{array}$ \\
\hline 1 Andersson $\mathrm{N}$ & $\geq 3$ & $\begin{array}{l}\text { Small copse } \\
\text { Liten holme }\end{array}$ & $0 \mathrm{~m} *$ & $\begin{array}{l}\text { Natural grass* } \\
\text { Naturligt gräs* }\end{array}$ & $\begin{array}{l}6 \text { June (feeding freq. } 12 \text { June) } \\
6 \text { juni (matningsfrekvens } 12 \text { juni) }\end{array}$ \\
\hline 2 Andersson $\mathrm{S}$ & $\geq 3$ & $\begin{array}{l}\text { Small copse } \\
\text { Liten holme }\end{array}$ & $5 \mathrm{~m} *$ & $\begin{array}{l}\text { Natural grass* } \\
\text { Naturligt gräs* }\end{array}$ & $\begin{array}{l}8 \text { June (feeding freq. } 14 \text { June) } \\
8 \text { juni (matningsfrekvens } 14 \text { juni) }\end{array}$ \\
\hline 3 Andersson W & $\geq 3$ & $\begin{array}{l}\text { Small copse } \\
\text { Liten holme }\end{array}$ & $\begin{array}{l}5 \mathrm{~m} \text { (bushes) } \\
5 \mathrm{~m} \text { (buskar) }\end{array}$ & $\begin{array}{l}\text { Spring wheat } \\
\text { Vårvete }\end{array}$ & $\begin{array}{l}21 \text { June (feeding freq. } 27 \text { June) } \\
21 \text { juni (matningsfrekvens } 27 \text { juni) }\end{array}$ \\
\hline 4 Lindåsa & $\geq 3$ & $\begin{array}{l}\text { Outside forest edge } \\
\text { Utanför skogskant }\end{array}$ & $15 \mathrm{~m}$ & $\begin{array}{l}\text { Herbs / natural grass } \\
\text { Örter / gräs }\end{array}$ & $\begin{array}{l}6 \text { June (feeding freq. } 12 \text { June) } \\
6 \text { juni (matningsfrekvens } 12 \text { juni) }\end{array}$ \\
\hline 5 Sörön & 2 & $\begin{array}{l}\text { Forest edge } \\
\text { Skogskant }\end{array}$ & $5 \mathrm{~m}$ & $\begin{array}{l}\text { Natural grass / edge } \\
\text { of ditch } \\
\text { Gräs / dikeskant }\end{array}$ & $\begin{array}{l}16 \text { June (judged age of nestlings) } \\
16 \text { juni (bedömd ålder på ungar) }\end{array}$ \\
\hline
\end{tabular}

* assumption, since no direct observation could be made | antagande, då ingen direktobservation kunnat göras 
TABLE 3. Observed foraging activities of Ortolan Bunting Emberiza hortulana at Kvismaren 2017, accounted for per nest. Numbers in regular font state the number of foraging trips, while numbers in italics represent the corresponding percentages. The first five foraging target columns are all within spring wheat fields, and the first four of those represent foraging trips to the sown crop in the interior of the field. For the four different field categories, the figure within parentheses represents the number of unsown rows. The different foraging areas are shown in Fig. 1.

- De fem ortolansparvsbona med tillhörande födsöksobservationer. Antal födosök är angivna i normalt typsnitt, medan motsvarande procentsatser är redovisade i kursiv stil. De första sex kolumnerna för födosöksmål är alla inom fält med vårvete, och de första fyra av dessa motsvarar födosöksrundor till den sådda delen av fältet. För de fyra olika fältkategorierna är antalet osådda rader angivet inom parentes. De olika födosöksområdena är redovisade i figur 1 .

\begin{tabular}{|c|c|c|c|c|c|c|c|c|c|c|c|c|c|c|c|c|c|c|c|c|}
\hline $\begin{array}{l}\text { Foraging target } \\
\text { (no. unsown rows) } \\
\text { Födosöksmål (antal } \\
\text { osådda rader) }\end{array}$ & \multicolumn{2}{|c|}{$\begin{array}{c}\text { Test field } \\
(1-3) \\
\text { Testfält } \\
\text { (1-3) }\end{array}$} & \multicolumn{2}{|c|}{$\begin{array}{l}\text { Anders- } \\
\text { son (2) }\end{array}$} & \multicolumn{2}{|c|}{$\begin{array}{l}\text { Bärsta (0) } \\
\text { patchy } \\
\text { Bärsta (0) } \\
\text { ojämnt }\end{array}$} & \multicolumn{2}{|c|}{$\begin{array}{l}\text { Other } \\
\text { fields (0) } \\
\text { Övriga } \\
\text { fält (0) }\end{array}$} & \multicolumn{2}{|c|}{$\begin{array}{l}\text { Uncultiv. } \\
\text { field border } \\
\text { Obrukad } \\
\text { fältkant }\end{array}$} & \multicolumn{2}{|c|}{$\begin{array}{l}\text { Ditch w. } \\
\text { wind soil } \\
\text { Dike } m . \\
\text { vindjord }\end{array}$} & \multicolumn{2}{|c|}{$\begin{array}{l}\text { Natural } \\
\text { grass } \\
\text { Naturligt } \\
\text { gräs }\end{array}$} & $\begin{array}{l}\text { Oat fr. } \\
\text { feeder } \\
\text { Havre fr. } \\
\text { matare }\end{array}$ & \multicolumn{2}{|c|}{$\begin{array}{l}\text { Tree } \\
\text { canopy } \\
\text { Träd- } \\
\text { kronor }\end{array}$} & \multicolumn{2}{|c|}{$\begin{array}{l}\text { Flying } \\
\text { insect } \\
\text { Flygande } \\
\text { insekt }\end{array}$} & \multirow[t]{2}{*}{$\begin{array}{l}\text { Sum } \\
\text { Sum- } \\
\text { ma }\end{array}$} \\
\hline \multicolumn{20}{|l|}{$\begin{array}{l}\text { Nest: no, name } \\
\text { Bo: nr, namn }\end{array}$} & \\
\hline 1 Andersson $\mathrm{N}$ & 4 & 14.3 & 15 & 53.6 & & & & & & & & & 3 & 10.7 & 13.6 & 5 & 27.9 & & & 28 \\
\hline 2 Andersson $\mathrm{S}$ & 10 & 18.9 & 36 & 67.9 & & & & & 2 & 3.8 & & & & & 11.9 & 4 & 7.5 & & & 53 \\
\hline 3 Andersson W & 3 & 14.3 & 13 & 61.9 & & & & & & & & 4.8 & & & & 4 & 19.0 & & & 21 \\
\hline 4 Lindåsa & & & 46 & 38.3 & & & 13 & 10.8 & 8 & 6.7 & 10 & 8.3 & 9 & 7.5 & 29 & 4 & 3.3 & 1 & 0.8 & 120 \\
\hline 5 Sörön & & & & & 48 & 98.0 & & & & & 1 & 2.0 & & & & & & & & 49 \\
\hline Total & 17 & 6.3 & & 40.6 & 48 & 17.7 & 13 & 4.8 & 10 & 3.7 & 12 & 4.4 & 12 & 4.4 & 31 & & 6.3 & 1 & 0.4 & 271 \\
\hline
\end{tabular}

parents brought to the nests, but most of the closer observations of birds that had foraged on the ground regarded dark, probably ground-dwelling, invertebrates in their beaks (see Appendix 3). Only one of the predated invertebrates observed in the field was green. (see Table 3).

The average distances of foraging trips (across all feeding parents; see Persson \& Sondell 2018) varied between nests: $47 \mathrm{~m}$ (nest 1), $64 \mathrm{~m}$ (nest 2), $114 \mathrm{~m}$ (nest 3), $103 \mathrm{~m}$ (nest 4), and $83 \mathrm{~m}$ (nest 5). The overall mean foraging trip distance was $82 \mathrm{~m}$ and longer trips than $200 \mathrm{~m}$ were unusual, with the maximum distance recorded at $250 \mathrm{~m}$ (however, note that this excludes the small fraction of flights at which the observers lost sight of the bird).

\section{FIELDS UTILIZED FOR FORAGING}

Out of the ten fields adjacent to the nesting areas, mainly three fields were used by the ortolans for foraging (Figure 1). Most of the unused fields close to the ortolan foraging fields or nests had no unsown rows (Figure 1). The three foraging fields were all sown with spring wheat and had varying numbers of unsown rows (no rows, two rows, and one to three rows, respectively). All three foraging fields were surrounded by unmanaged field borders of approximately $2 \mathrm{~m}$ width, present as a management measure for the ortolans. The main foraging fields were characterized as follows:

\section{Bärsta (Foraging field 1)}

This field was for some reason - maybe due to patches of poor sandy soil - unevenly sown or germinated,

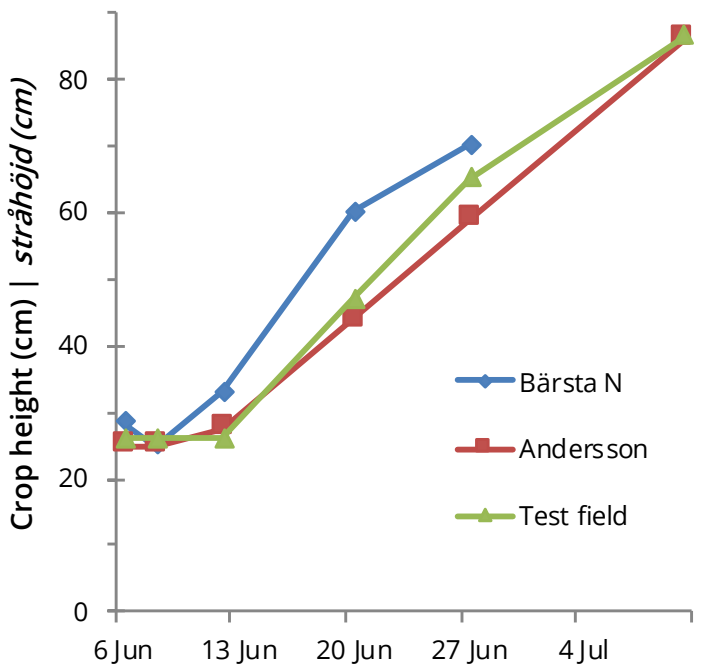

FIGURE 3. Height of spring wheat at different dates for the main foraging fields.

- Sädens höjd (vårvete) i centimeter vid olika tidpunkter i de huvudsakliga födosöksområdena. 
causing variation in crop height and presence of patches with low or no crop coverage. There was a larger unsown patch similar to a "lark plot", i.e. an agro-environment solution to provide open areas for foraging within crops, that has been used to encourage skylarks to breed away from tractor tracks (Sondell 2017; Figure 1). See also the foraging field 1 work map in Appendix 2. This field is closest to Sörön and was only visited by the female from the Sörön nest (nest 5).

\section{Test field (Foraging field 2)}

At the time of chick feeding, the crop was fairly high (around $0.3 \mathrm{~m}$ for three early nests and $0.6 \mathrm{~m}$ for two late nests, see Figure 3) and parts of the unsown tractor tracks were largely colonised by arable weed growth (Figure 4a). It was therefore difficult to see from the observation points which of the alternative tractor tracks - i.e. with how many unsown rows - the birds visited. The tractor tracks were also $24 \mathrm{~m}$ apart (compared to only $12 \mathrm{~m}$ in the Andersson field; see below and Discussion). An ungerminated patch of approximately $32 \mathrm{~m} 2$, similar to a lark plot, was also present in this field (Figure 1), however this was not utilized by the foraging ortolans.

\section{Andersson (Foraging field 3)}

This field is situated east of and around the Andersson copse, and it held two nests (Figure 1). The field had tractor wheel tracks with two unsown rows $12 \mathrm{~m}$ apart. It was the field which was most frequented by the ortolans, visited by four out of five females.

\section{CROP HEIGHT AND WEED COVER}

Crop height increased during the breeding season with some variation between fields (Figure 3). The Andersson and the Test field developed similarly while the northern part of the Bärsta field (Figure 1) was 5 to $10 \mathrm{~cm}$ higher than the former ones at comparable dates (Figure 3). The field to the east of Andersson had the same height as the northern part of the Bärsta field. The fields close to the nest 4 (Lindåsa) were a few centimetres shorter than the Andersson field. Parts of the Bärsta field was clearly shorter and thinner and with plenty of small patches compared to the northern
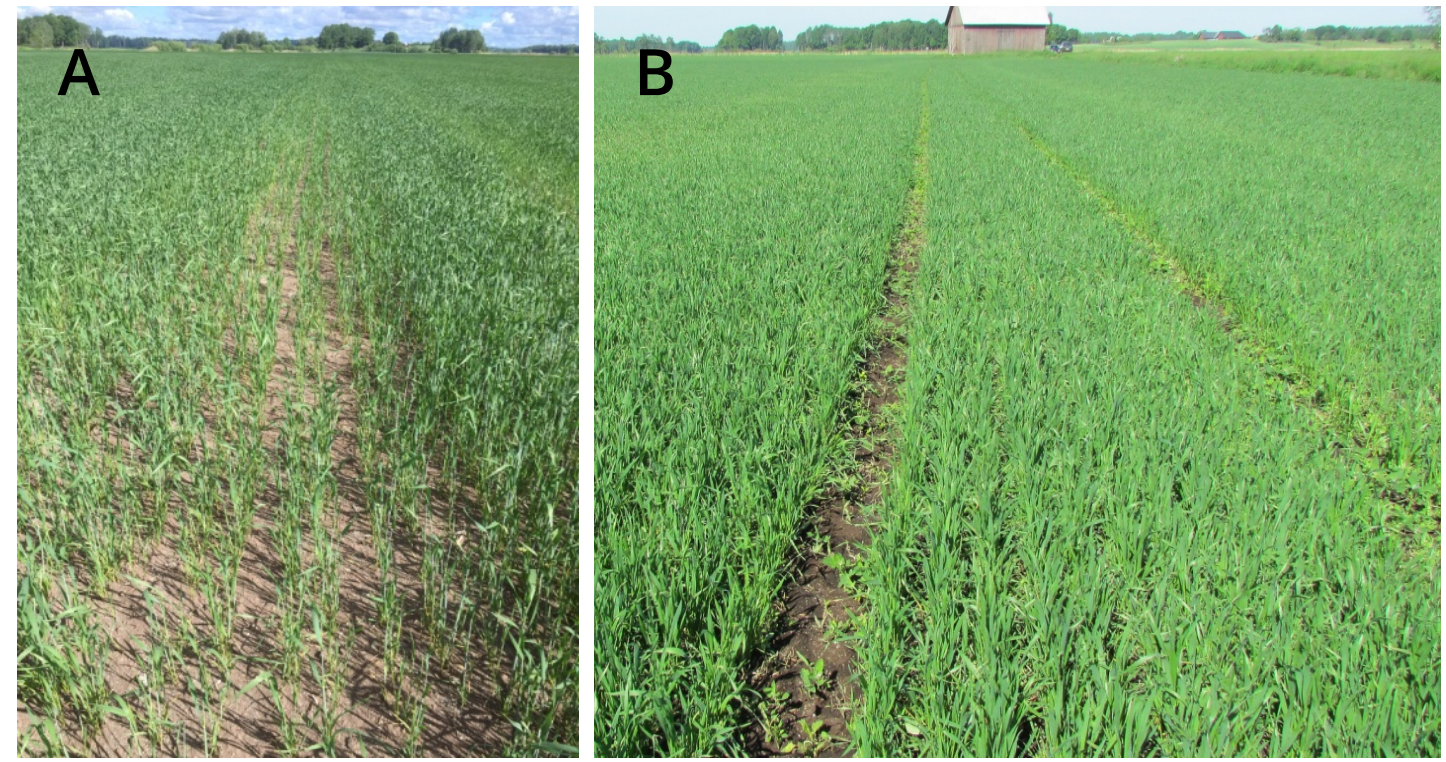

FIGURE 4. Photos comparing crop growth along wheel tracks in fields with and without unsown rows, from head height. Two ways of making fields more attractive as foraging habitats for Ortolan Buntings Emberiza hortulana: (a) Two sowing rows unsown in each wheel track at Andersson on 13 June. Note the variation of weed cover within the tracks. (b) Shorter and thinner crop but no unsown rows at the southern parts of the Bärsta field east of Sörön on 20 June. Photos: Jan Sondell (a) and Magnus Persson (b).

- Två sätt att göra fälten mer attraktiva som födsöksplatser för ortolansparv Emberiza hortulana. (a) Två osådda rader $i$ varje hjulspår på Anderssons fält 13 juni. Notera variationen av ogräs i spåren. (b) Kortare och glesare gröda men inga osådda rader på Bärstafältet öster om Sörön 20 juni. Foto: Jan Sondell (a) och Magnus Persson (b). 


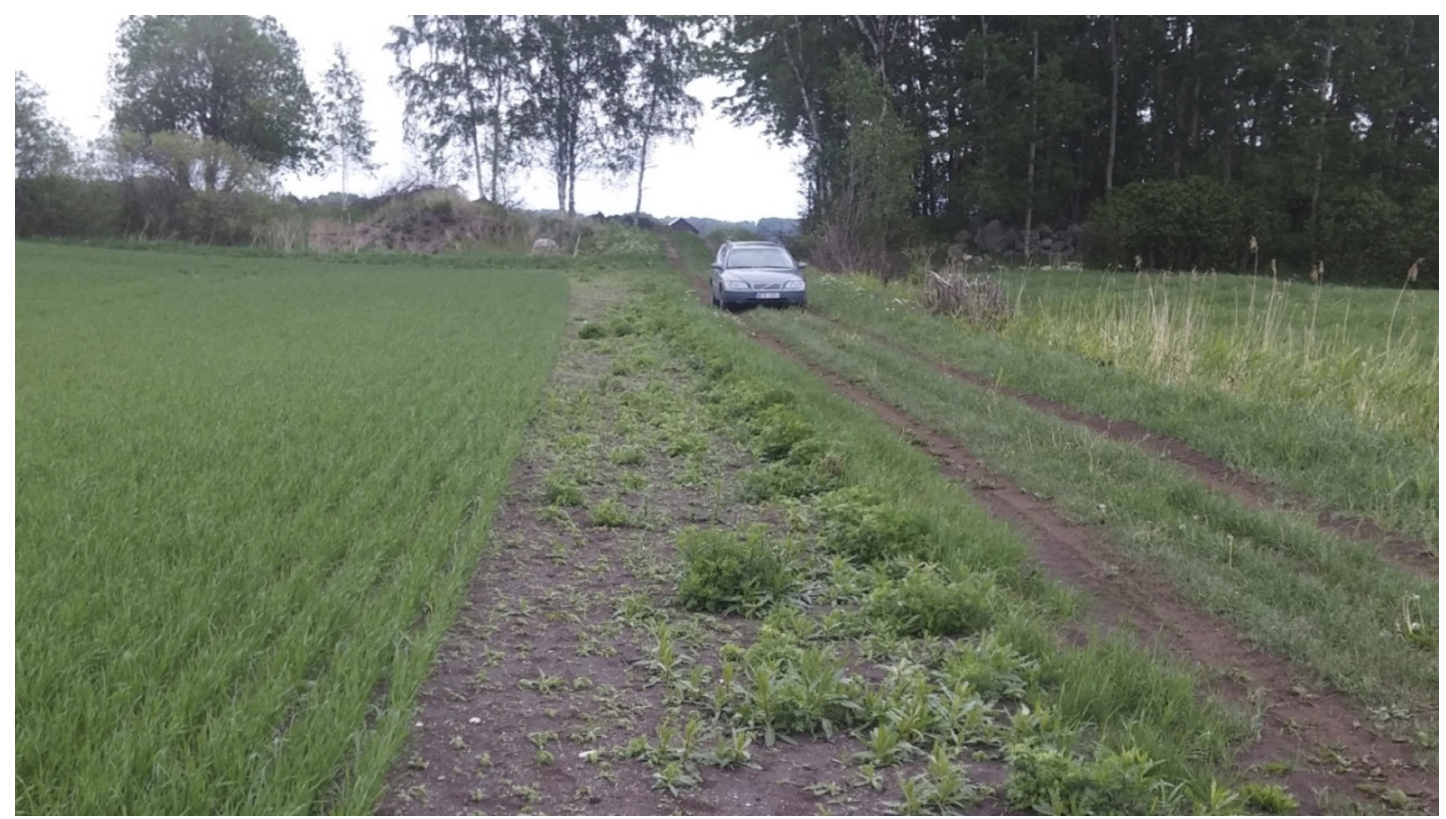

FIGURE 5. Uncultivated field border at the southern border of the Test field on 13 June. Weed covers less than $50 \%$ of the strip area and it is therefore not necessary to harrow. Photo: Jan Sondell.

- Obrukad fältkant i södra kanten av testfältet den 13 juni. Ogräs täcker mindre än 50 \% av remsan och det är därför inte nödvändigt att harva. Foto: Jan Sondell.

part of the same field (cf. Appendix 2). The height of the crops was fairly similar for all surrounding fields, all sown with spring seed.

Overall weed coverage of tractor wheel tracks (cf. Figure $4 \mathrm{a}$ ) was on average $15.2 \%$ (range: o-60\%, $\mathrm{SD}=11.6 \%, \mathrm{n}=173)$ and did not differ between the Test and Andersson field. While there were some differences in weed cover between tracks of different number of unsown rows, there were significant differences between sampling sites within the same field and number of unsown rows, and our sampling design did not allow separate estimation of the effect of number of unsown rows (ANOVA: F5,67=6.96, $\mathrm{r}^{2}=0.17, \mathrm{p}<0.001$ ). Uncultivated field borders (Figure 5), specifically prepared for the ortolans, were visited infrequently ( $3.7 \%$ of foraging trips; Table 3). Ditches were used if there was bare soil at the bottom (4.4\%; Table 3) as strong winds during spring had moved dry soil with high organic content from the surface of the fields to the ditches and created a layer of bare soil. Natural grass covered a limited area, however most nests were placed in this habitat (Table 2).

\section{Discussion}

\section{FORAGING HABITS}

While we could only make incidental observations of the type of food collected by the feeding parents, observations were made daily and most of them regarded dark invertebrates (Appendix 3). Foraging was predominantly carried out on the ground, on which the abundance of invertebrates in different farmland habitats was assessed by Sondell (2017). He collected 1,674 invertebrates at an average mass of $70 \mathrm{mg}$, distributed over 80 taxa. Most of the collected taxa were dark-coloured and thus blended with the soil colour (Sondell 2017), consistent with the prey selection observed in the present study and in Switzerland (Menz et al. 2009).

Judged from the observations at Kvismaren the average flight distance of $82 \mathrm{~m}$ to the foraging areas (mean 47-114 $\mathrm{m}$ for the individual nests) is moderate compared to skylarks in autumn-sown crops in Kvismaren, where the mean distance was $204 \mathrm{~m}$, likewise the maximum distance was shorter: $250 \mathrm{~m} \mathrm{v} .550 \mathrm{~m}$ (Sondell 2017). The ortolan parents often repeatedly returned to the same places where they had last foraged. 
What is characterizing different types of utilized crop fields in our study area (Figure 1)? Parents at all nests preferentially foraged on fields with unsown rows or bare patches. Three of the nests (nests 1-3, Andersson) were situated in fields with unsown sowing rows (Figure 2), and parents also mainly foraged in those fields (Table 3). Nest 5 (Sörön) was situated at the edge of the patchy Bärsta field, and the female foraged almost exclusively on that field, and did not fly further to the fields with unsown rows (Table 3, see Figure 1). Neither was she ever observed to visit the nearby set-aside to the NW or the potato field to the W (Figure 1). Hence four of the five nests were situated in, or at the edge of, fields with patches or unsown rows, which may reflect a nest site preference based either on foraging opportunities or other features (such as e.g. perceived risk of predation or exposure to weather). This means that the preferential foraging in fields with unsown rows or patches could simply reflect that these fields were the foraging grounds available at the smallest distance for the parents.

However, nest 4 (Lindåsa), was situated at the edge of a field with no unsown rows, and despite such fields being closest to the nest, the female (the polygynous male did not help feeding this nest very much; Persson \& Sondell 2018) foraged more than three times as often further away at the Andersson field, with two unsown rows, than at nearby fields with no unsown rows (Figure 1). We acknowledge that this is a single observation, but argue that it shows a clear pattern of preference of foraging in unsown sowing rows. Our observations do not allow distinguishing specific preferences for width (number of unsown rows) of the unsown tracks in the Test field, but the highly frequented Andersson field had two unsown rows per wheel track spaced at $12 \mathrm{~m}$.

\section{IMPORTANCE OF DIFFERENT FORAGING HABITATS OR FOOD SOURCES}

In the ortolan study area in NE Kvismaren, the soils with high organic content are unsuitable for autumn-sown crop, as there is a significant risk for ice lift during winter, which kills off the roots of the small plants. Instead spring-sown crop is the dominant feature in the study area, and this becomes high and dense later in the year than the autumn-sown crop, which allows favourable foraging conditions for the ortolans (Berg 2008). However, spring rains are affecting soil stability of fields with high organic content more severely, and over longer time, than fields with clay soils. Given the flat landscape, drainage of water is slow in spring and tractors can access fields with high organic soil content later than fields with clay soil, hence the former are usually sown later in spring.

The foraging habitats or specific food sources at Kvismaren that were utilized by ortolans can be grouped into six main categories, for which feeding frequency and subdivisions are listed in Table 3. Here, we characterize these habitats or food sources, in descending order of utilization (fraction of the total foraging trips stated within parentheses):

\section{Unsown sowing rows in tractor wheel tracks (46.9\%)}

In later years unsown sowing rows (Figure 2) have become more common (for technical information about unsown rows, advantages etc., see Sondell 2017). These openings in the field are used extensively by foraging ortolans, but even if unsown rows are common nowadays they are not applied by all farmers. For technical reasons, they yield less of an advantage for the farmer in smaller fields with irregular borders, such as the fields enclosing copses that are utilized for nesting and foraging by the ortolans. However, even if no sowing rows are left unsown, we occasionally observed ortolans foraging in the depressed crop of wheel tracks (MP, pers. obs.).

\section{Sparse sowing or small bare patches in the crops (22.5\%)}

In some fields the sowing is not entirely even, for various potential reasons like sandy soil or water/ice killing plants (the latter particularly in autumn-sown crops). Small bare or sparsely sown patches can be exploited by foraging ortolans (Menz et al. 2009, Menz \& Arlettaz 2011), as was the case at the Bärsta field (Foraging field 1; Figure 1, 3 and 4b). In general, fields have become more uniform and the crops have become denser over the decades, which could prevent ortolans from foraging there. Irregular crop growth cannot be expected to produce stable foraging opportunities over time.

\section{Supplemental oat feeders (11.4\%)}

Supplemental feeding with oats was carried out in ortolan territories from early May 2017 to support the adults upon arrival, when it can sometimes still be cold and rainy. Feeders were placed in two territories at 
Kvismaren - nest 4 (Lindåsa) and between nest nest 1 and 2 (Andersson; Figure 1) - and the feeding was kept active throughout the breeding season. The parents of the Lindåsa nest made close to a quarter of their foraging trips to oat feeders, mainly in the late growing stage of the nestlings and after the chicks had fledged, whereas other parents rarely visited the feeder (Table 3).

\section{Canopy of trees and bushes (6.3\%)}

According to our experience, if the abundance of prey species is unusually high in trees and bushes - e.g. by irruptions of green oak moth Tortrix viridana on oak, or of bird-cherry ermine Yponomeuta evonymella on bird cherry - ortolans may shift feeding behaviour and primarily feed in the canopy instead of on the ground. In Kvismaren, this happens at an irregular basis, at an estimated frequency of one to two years per decade (MP \& JS, pers. obs.). Even during years with ordinary abundance of canopy-dwelling prey, some ortolan foraging is usually targeting this (Stolt 1974); in the present study this corresponded to $6.3 \%$ of the total number of observed foraging events (Table 3 ).

\section{Uncultivated field borders (3.7\%)}

To improve the foraging habitat, uncultivated field borders have been recommended in areas with ortolan territories (Sondell et al. 2011, Naturvårdsverket 2017). This means preserving 1-3 $\mathrm{m}$ wide harrowed, unsown strips along the borders of the fields (Figure 5) recommended at a total length of $\geq 1 \mathrm{~km}$ per pair, corresponding to 0.3 ha (Naturvårdsverket 2017). Such uncultivated field borders are also in accordance with EU recommendations (Jordbruksverket 2016). However, the uncultivated field borders were surprisingly seldom visited ( $3.7 \%$ of all observed foraging trips), and furthermore, the lark plots were not visited at all. This might be explained by the fact that there were better options present. However, the two lark plots also represented a very small area of bare soil, compared with the unsown rows. Based on our observations from previous years - and supported by the behaviour of the Sörön female (Figure 1, Table 3) - we know that an ortolan pair only needs a few hundred square meters of ground if the foraging habitat is good.

Other positive factors ( $9.2 \%$ )

There were three additional foraging sources registered in the study: (1) Ditches containing eroded soil, which had been moved from the field surface by strong winds in dry weather; (2) natural grass close to the nests; and (3) flying insects (Table 3). If the soil layer is disturbed by fire (Menz et al. 2009), new cultivation (Nævra 2002), drainage, construction work, etc., the exposed soil can be used by ortolans (Naturvårdsverket 2017; not present in this study). However such opportunities are rare and cannot be expected to provide good foraging circumstances over time (Stolt 1974, Dale 1997).

\section{GENERAL BREEDING REQUIREMENTS}

We suggest that in a good ortolan breeding habitat the most important requirements to be fulfilled are:

1. Singing posts for the male. Territories in entirely open fields, as used by skylarks (Alauda arvensis; Sondell 2017) are not used by ortolans (Rosenberg 1953, own observations). However, the singing post only need to be a few metres high, e.g. some bushes, rocks, or a telephone / electric wire. In this study, nest 1 (Andersson $\mathrm{W}$ ) was in a territory in which the highest singing posts were $5 \mathrm{~m}$ high bushes.

2. Suitable natural grass or crops of appropriate height to hide the nest in late May or early June (cf. Table 2). According to our experiences from this and previous breeding seasons, the grass ought to be at least $0.2 \mathrm{~m}$; however it may be fairly high and mixed with bushes $(<1.5 \mathrm{~m}$, not too dense if close to the maximum height).

3. Suitable foraging grounds with bare soil in a desired mix with sheltering vegetation in the middle of June (further details in this study).

To generate good breeding habitats for ortolans it is important that all three requirements are met. In Kvismaren, requirement 1 is easy to fulfil as there are many small copses or fields bordering deciduous forests in parts of the valley. The copses have also been trimmed by removing undergrowth and thinning of higher stems in the last eight years.

Requirement 2 is also easy to fulfil, since nests can be built in natural grass or within autumn-sown or spring-sown crops, as described by Rosenberg (1953). Around 20 nests have been found in these habitats during the years 2009-2017 at Kvismaren (Sondell et al. 2011, Sondell 2013, this study). In contrast, in Bavaria, Germany, requirement 2 is regarded the most difficult, 
as most fields are covered with high and dense winter crop already when the ortolans arrive in the beginning of May (Dagmar Koppeloer, LBV, pers. comm.). Requirement 3 could be the easiest to fulfil in Bavaria because in many places fields are sown with sunflowers or corn with a distance of $0.25-0.75 \mathrm{~m}$ between rows (JS, pers. obs.).

It is possible that requirement 3 is presently not sufficiently fulfilled at Kvismaren, even though we have pointed out several types of food extraction grounds. The population is currently decreasing, despite the implementation uncultivated field borders for several years and despite most farmers leaving unsown rows in tractor wheel tracks. The last expansive period for ortolans in the Kvismaren valley was around 1980-2000 (annual censusing by Kvismare Bird Observatory), see Appendix 1. Following the widening of the canal draining Kvismaren from 15 to $30 \mathrm{~m}$ in 1970 , a new ditch network was worked out in the extensive agricultural area around Sörön after embankment. Digging out these new ditches resulted in strings of bare soil being deposited across the fields, and this process occurred over many years, which can be seen by comparing national aerial photos from Lantmäteriet from the years 1950, 1961, 1980 and 1997. The circumstances during this period were very similar to the German example below and might provide a clue to breeding requirements.

The only known expansion of ortolans in continental northern Europe in the later decades occurred in Germany. In Wendland, Niedersachsen, draining of wet meadows to gain crop fields brought an ortolan population to expand from close to zero to around 300 pairs (Deutsch 2007, Siegfried Spalik, pers. comm. 2016). During several years of exploitation in the beginning of the 21st century, digging ditches and putting down underground drain-ditches to lower the ground water levels, combined with the removal of trees, bushes, and tussocks all over the area, created seemingly optimal circumstances for breeding ortolans (Deutsch 2007, Siegfried Spalik, pers. comm. 2016).

The German ortolans pass the same French poaching area on migration and winter in the same area in West Africa as the Swedish ortolans (Selstam et al. 2015, Bernardy 2016). Nevertheless, the German population expanded despite these shared potential threats. Given this, and no general lack of singing post and suitable grass cover for nests in our study area, we argue that the main cause of the decrease in the Kvismaren (and the Swedish) population is limited access to food on the breeding grounds, due to changed farming practices (cf. Wretenberg et al. 2007). Indeed, requirement 3 is the most difficult to meet at Kvismaren as crops sown with wider distance between rows - such as the Bavarian sunflower or corn fields - are uncommon in central Sweden.

\section{METHODOLOGICAL SHORTCOMINGS}

We encountered some difficulties employing our methodology: (1) We experienced that the sexes were hard to separate in the field, particularly as some males and females had similar plumage. (2) It was very hard to see exactly where a bird landed, when it was foraging within a field. (3) Assessing what food adults had in their beak was often difficult, particularly in the beginning of the foraging period when the invertebrates that they caught were very small. We therefore encourage further research on habitat selection and feeding behaviour of Ortolan Buntings in Sweden.

\section{Conclusions and management recommendations}

This study indicates that Ortolan Buntings at Kvismaren mainly search for ground invertebrates on small areas or strips of bare soil in the spring-sown crop fields. The need for bare soil has previously been established (Menz et al. 2009, Menz \& Arlettaz 2011, Morelli 2012), and Brambilla et al. (2016) could establish this as the most important factor in the selection for territories, with an optimal fraction of bare ground estimated at $5-20 \%$. Foraging ortolans seem to avoid feeding in completely bare areas, such as broader uncultivated field borders, probably to reduce predation risk. Instead, we show that they prefer to feed in small patches of bare ground within fields, which was the target for no less than $70 \%$ of the foraging trips that we observed. An optimal foraging habitat likely includes a mix of bare ground and vegetation, and our study shows that this can be provided within crops that contain unsown sowing rows or other patches of low or sparse crop growth.

\section{MANAGEMENT RECOMMENDATIONS}

Naturvårdsverket (2017) recently employed a management plan for the Swedish population of Ortolan Bun- 
ting. In accordance with the present study, availability of suitable nesting areas and bare soil for foraging is highlighted. However, our study identifies details of the management plan that we suggest be revised. Thus, in areas with Ortolan Buntings, we recommend the following preparations to be carried out for all known territories on farmland in Sweden, where cereal crops are likely to be used for foraging.

\section{Priority 1: Bare soil interspersed within fields}

While the availability of bare soil for foraging was identified as an important factor in the recent management plan for the species, Naturvårdverket (2017) recommended that the bare soil should be left as $2-3$ $\mathrm{m}$ broad uncultivated field borders. Our study shows that broader uncultivated field borders are used $<1 / 10$ as often as narrow strips of unsown bare soil within fields:

- Ensure that crop fields in the vicinity of known territories / nesting sites will have two sowing rows left unsown within each tractor wheel track. Select field(s) situated within $200 \mathrm{~m}$ from the probable nest area, and if tractor tracks are spaced at $12 \mathrm{~m}$, we suggest this practice is applied to c. 4 hectares, whereas if the tracks are spaced at $24 \mathrm{~m}$, the area ought to be doubled.

- This sowing practice can be applied to both autumn-sown and spring-sown crop.

- If the land owner does not have access to a sowing device that can produce unsown rows, we recommend that a contractor is hired to do this job.

\section{Priority 2: Copses as nesting sites}

In accordance with Naturvårdverket (2017), we find that small copses in the fields are very important as nesting sites for ortolans:

- Undergrowth should be cleared.

- Higher trees should be left in a sparse configuration (10 $\mathrm{m}$ between trees).

\section{Priority 3: Narrow uncultivated field borders}

Five farmers in The Kvismaren valley have left 2-3 m wide uncultivated field borders since the beginning of the 2010s (Sondell 2011), an action that is now recommended by Naturvårdsverket (2017) and the EU (Jordbruksverket 2016). This is a simple action for the farmer, and can act as an assurance against lack of food if there are no unsown sowing rows or if the unsown tracks are overgrown by weeds. Our study shows that the foraging ortolans may avoid larger open areas, and we therefore suggest reducing the width of the uncultivated field borders in favour of preserving bare soil within the field (Priority 1):

- Leave 1 (2) m wide unsown strips along the borders of field(s) adjacent to territories / nesting sites (Figure 5).

- We recommend a length of $1 \mathrm{~km}$ per ortolan pair.

\section{Alternative actions}

If Priority 1 and 3 for some reason cannot be achieved, there are alternative actions that may suit the planning of the farmer better, which can employed to partly address the need for bare soil:

- Sparse or late sowing.

- Harrowing of already sown crop is an option if the territory is found late in the season.

\section{Warning}

Silage fields in the vicinity of ortolan territories constitute a risk as a nest may be placed in that grass. In order to avoid destroying the nest and chicks, it would be preferable if the harvest of the silage field, or at least a part of it, could be delayed until after fledging in early July.

Further monitoring would be valuable to confirm and fine-tune these recommendations.

\section{Acknowledgements}

We especially thank the land owners Jakob Gunnarsson, Torbjörn Malmgren, Leif Nilsson and the late Arne Andersson for allowing us to trample their wheat fields when walking to observation posts etc. We thank the ortolan observers Cristina Sellarés and Ana Navarro for long-lasting observations of feeding ortolans. We thank Juliana Dänhardt and two anonymous reviewers for ample constructive feedback on a previous version of this manuscript, and the editor for assistance with the revision process. Kvismare Bird Observatory lodged the field workers for about two months. This project was supported by the County Administrative Board in Örebro. This is contribution no. 188 from Kvismare Bird Observatory. 


\section{References}

Artportalen, SLU. 2018. Artportalen - rapportsystem för växter, djur och svampar. Available at https://www.artportalen.se, accessed in 2018.

Berg Å. 20o8. Habitat selection and reproductive success of Ortolan Buntings Emberiza hortulana on farmland in central Sweden - the importance of habitat heterogeneity. Ibis 150: $565^{-5} 573$. https://doi. org/10.1111/j.1474-919x.2008.00825.x

Bernardy P. 2016. Ortolanprojekt: erste Ergebnisse der Zugstrategie wenderländicher Ortolaner. Presentation at a Swedish-German ortolan meeting in Bavaria 10-11 June 2016.

Brambilla M, Gustin M, Vitulano S, Negri I \& Celada C. 2016. A territory scale analysis of habitat preferences of the declining Ortolan Bunting Emberiza hortulana. Bird Study 63(1): 52-57. https://doi.org /10.1080/00063657.2015.1126219

Dale S. 1997. Hortulan - en direkte truet fugleart. Vår Fuglefauna 20: 33-38.

Dale S. 2ooo. The importance of farmland for Ortolan Buntings nesting on raised peat bogs. Ornis Fennica 77: 17-25.

Dale S, Frode B \& Olsen G. 2002. Use of farmland by Ortolan Buntings (Emberiza hortulana) nesting on a burned forest area. Journal für Ornithologie 143: 133-144. https://doi.org/10.1007/BFo2465445

Deutsch M. 2007. Der Ortolan Emberiza hortulana im Wendland (Niedersachsen) - Bestandszunahme durch Grünland Umbruch und Melioration? Vogelwelt 128: 105-115.

Durango S. 1948. Notes sur la reproduction de bruant ortolan en Suède. Alauda 16: 1-20.

Green M, Haas F \& Lindström Å. 2018. Monitoring population changes of birds in Sweden. Annual report for 2017. Department of Biology, Lund University. 95 pp.

Jiguet F, Arlettaz R, Bauer H-G, Belik V, Copete JL, Couzi L, Czajkowski MA, Dale S, Dombrovski V, Elts J, Ferrand Y, Hargues R, Kirwan GM, Minkevicius S, Piha M, Selstam G, Skierczyński M, Siblet J-P \& Sokolov A. 2016a. An update of European population sizes and trends of the Ortolan Bunting (Emberiza hortulana). Ornis Fennica 93: 186-196.

Jiguet F, Arlettaz R, Belik V, Bernardy P, Copete JL, Czajkowski MA, Dale S, Dombrovski V, Elts J, Ferrand Y, Minkevicius S, Piha M, Selstam G, Skierczyński M, Siblet J-P \& Sokolov A. 2016b. Migration strategy of the Ortolan Bunting: Final report of the scientific committee. 97 pp. Muséum National d'Histoire Naturelle, Paris. Available at https://bit.ly/2Y4QQVq.

Jordbruksverket. 2016. Ekologiska fokusarealer. Available at http:// www.jordbruksverket.se/amnesomraden/stod/jordbrukarstod/ stodochersattningar/forgroningsstod/villkor/ekologiskafokusarealer.4.2587b71d1525a28283862174.html.

Menz MHM \& Arlettaz R. 2012. The precipitous decline of the ortolan bunting: time to build on scientific evidence to inform conservation management. Oryx 46: 122-129. https://doi.org/10.1017/ so030605311000032

Menz MHM, Mosimann-Kampe P \& Arlettaz R. 2009. Foraging habitat selection in the last Ortolan Bunting Emberiza hortulana population in Switzerland: final lessons before extinction. Ardea 97(3): 323-333. https://doi.org/10.5253/078.097.0308

Morelli F. 2012. Correlations between landscape features and crop type and the occurrence of the Ortolan Bunting Emberiza hortulana in farmlands of Central Italy. Ornis Fennica 89: 264-272.

Nævra A. 2002. Hortulanens skjebnetime. Vår Fuglefauna 25: 62-81. Naturvårdsverket. 2017. Åtgärdsprogram för ortolansparv 2017-2021. Rapport 6781, april 2017.

Ottosson U, Ottvall R, Elmberg J, Green M, Gustafsson R, Haas F, Holmqvist N, Lindström $\AA$, Nilsson L, Svensson M, Svensson S \& Tjernberg M. 2012. Fåglarna i Sverige - antal och förekomst. Sveriges
Ornitologiska Förening, Halmstad.

Ottvall R, Green M, Lindström Å, Svensson S, Esseen P-A \& Marklund L. 20o8. Ortolansparvens Emberiza hortulana förekomst och habitatval i Sverige. [Distribution and habitat choice of the Ortolan Bunting Emberiza hortulana in Sweden]. Ornis Svecica 18: 3-16. https://doi.org/10.34080/os.v18.19596

Persson M, Selstam G, Sondell J \& Olsson P. 2015. Var tillbringar ortolanhannen vid Lindåsabacken vintern? Fåglar $i$ Kvismaren 30: 8-9.

Persson M \& Sondell J. 2018. Den andra kända observationen av polygyni hos ortolansparv Emberiza hortulana. [Second known record of polygyny in Ortolan Bunting Emberiza hortulana]. Ornis Svecica 28: 74-76. https://doi.org/10.34080/os.v28.19533

Rosenberg E. 1953. Fåglar i Sverige. Svensk natur, Uppsala.

Runesson B \& Jönsson K. 1987. Inventering av ortolan- och gulsparv vid Kvismaren 1965-1986. Fåglar i Kvismaren 2: 2-12.

Selstam G, Sondell J \& Olsson P. 2015. Wintering area and migration routes for Ortolan Buntings Emberiza hortulana from Sweden determined with light-geologgers. Ornis Svecica 25: 1-14. https://doi. org/10.34080/os.v25.19599

Sondell J, Brookes C \& Persson M. 2011. Ortolan Bunting Emberiza hortulana at Kvismaren, central Sweden - breeding studies and suggested management. Ornis Svecica 21: 167-174. https://doi. org/10.34080/os.v21.1960o

Sondell J. 2012. Läget är kritiskt för ortolansparven i mellersta Sverige. Fåglar i Kvismaren 27: 2-6.

Sondell J. 2013. Aktuellt om ortolansparven 2012-2013. Fåglar $i$ Kvismaren 28: 8-13.

Sondell J, Hansson P, Jerling N-O, Lindström J \& Selstam G. 2014. Inventering av ortolansparv på hyggen $i$ Norrland. Available at http:// birdlife.se/fagelskydd/jordbruk/projekt-ortolansparv/, "Rapport från Inventering av ortolansparv på hyggen i Norrland 2014".

Sondell J. 2016. Studier av de åkerhäcknade tättingarna sånglärka och ortolansparv. Fåglar i Kvismaren 31: 12-17.

Sondell J. 2017. Are large fields of autumn crop at Kvismaren, central Sweden commonly used as nesting and food search habitats for Skylark Alauda arvensis? Ornis Svecica 27: 41-56. https://doi. org/10.34080/os.v27.19556

Stolt B-O. 1974. Gulsparvens Emberiza citrinella och ortolansparvens Emberiza hortulana förekomst vid Uppsala under 1960-talet. Vår Fågelvärld 33: 210-217.

Stolt B-O. 1993. Notes on reproduction in a declining population of the Ortolan Bunting Emberiza hortulana. Journal für Ornithologie 134: 59-98. https://doi.org/10.1007/BFo1661133

Steifetten $\varnothing$ \& Dale S. 2006. Viability of an endangered population of ortolan buntings: The effect of a skewed operational sex ratio. Biological conservation 132: 88-97. https://doi.org/10.1016/j. biocon.2006.03.016

Wretenberg J, Lindström Å, Svensson S \& Pärt Å. 2007. Linking agricultural policies to population trends of Swedish farmland birds in different agricultural regions. Journal of Applied Ecology 44: 933-941. https://doi.org/10.1111/j.1365-2664.2007.01349.x 


\section{Svensk sammanfattning}

\section{INLEDNING}

Ortolansparven har minskat starkt i Sverige under många decennier. Idag finns mindre än 100 kända revir kvar söder om Limes Norrlandicus. Birdlife Sverige har startat ett projekt för att förstå nedgången och stödja skötselåtgärder. Naturvårdsverket godkände en åtgärdsplan (ÅGP) i april 2017. Orsakerna till nedgången har tidigare varit oklara men idag anser man att jordbrukets rationalisering är huvudorsaken.

Ortolansparven kan uppträda i skiftande miljöer. Förutom huvudhabitaten på åkermark och på nyupptagna hyggen i Norrland kan den förekomma i brandområden, på mossmark med täktverksamhet, industriområden inkluderande startbanor och järnvägar, men även i energiskog och i grustag. Födan hämtas från marken men det har varit osäkert hur ett bra födosökshabitat ska vara utformat.

Vid Kvismaren har arten sin sydvästligaste utbredning i landet och här har ortolanerna varit föremål för studier sedan 2009. Populationen har minskat och de senaste två åren har fyra respektive fem honor byggt bo. År 2017 fanns det bara fyra gamla häckande hannar till de fem honorna, varav en färgmärkt hanne var polygam (Persson \& Sondell 2018).

Ortolansparven är beroende av att hämta födan på bar mineral- eller torvjord. Jordbrukslandskapet $\mathrm{i}$ Kvismaren blir som andra odlingsområden för stråsäd grönt när säden grott och den huvudsakliga orsaken till nedgången är troligen att det saknas jord utan vegetation och därmed lämpliga födosökshabitat för ortolansparven från maj till början av juli.

\section{SYFTE}

Målsättningen var att undersöka vilken typ av föda ortolansparven eftersöker och i vilken miljö detta sker med hänsyn till marktäckning, sädesslag och närhet till angränsande träddungar och skogskanter som kan tjäna som häckningshabitat. Genom att i detalj veta var ortolanen hittar sin föda är det lättare att erbjuda ett bättre födosökshabitat och på så sätt skydda denna hotade fågelart. Avsikten var också att på grundval av resultaten formulera allmänna skötselrekommendationer.

\section{STUDIEOMRÅDE}

De nio gamla ortolansparvarnas födosök har studerats i nordöstra Kvismardalen (figur 1). Av figuren framgår var bona var lokaliserade. På kartan framgår vad som karaktäriserar de olika åkrarna och såddmönstren med avseende på osådda rader. I huvudsak födosökte ortolanerna på tre fält: "Bärsta" där det fanns gles säd och luckor i grödan, "Andersson" där det fann två osådda rader per traktorhjulspår, med $12 \mathrm{~m}$ avstånd mellan traktorstråken, och på ett särskilt "testfält" varierades antalet osådda rader mellan en och tre. Där hade traktorn passerat med $24 \mathrm{~m}$ avstånd mellan stråken. Två "lärkrutor" (Sondell 2017) fanns också av misstag, se figur 1.

Data angående de olika bona 2017 framgår av tabell 2. Hela området karaktäriseras av att det där enbart förekommer torvjord, vilket gör att ogräs lätt etablerar sig. Sädens stråhöjd vid olika datum under försommaren framgår av figur 3. Anderssons fält och testfältet var ungefär lika höga medan Bärstas fält var $5^{-10} \mathrm{~cm}$ högre i den norra änden vid jämförbara tidpunkter. I den södra delen av Bärstas fält var säden signifikant kortare (jfr appendix 2).

\section{METODIK}

När ortolansparven återkommer från vintervistelsen i Västafrika börjar den omedelbart att sjunga, vilket gör att man snabbt kan bilda sig en uppfattning om var och hur många hannar som finns i området. Honorna är mer svårsedda och kan oftast bara återfinnas tillsammans med hannarna. Man ser lite mer av dem i samband med bobyggnaden, men först när matningen av ungarna påbörjas blir båda könen mer lättobserverade.

Studiemetodiken var observationer på så nära håll som möjligt utan att störa. Att sitta i en bil var ofta ett utmärkt alternativ. Alla observationer dokumenterades på grundkartor utskrivna från Google Maps (appendix 2) där det var lätt att orientera sig efter aktuella åker- och skogskanter. Alla avstånd mättes via Googles linjalverktyg. Enbart födosöksrundor där observatören sett var fågeln slagit ner för att söka föda har registrerats. Rundor då fågeln försvunnit ur synhåll ingår inte. De var också 
relativt få. Att tre av fem hannar (en oparad) var färgmärkta underlättade könsidentifieringen.

Det fanns svårigheter med den beskrivna metoden. Det var ofta svårt att bestämma kön på fåglarna, särskilt som vissa par hade liknande dräkter. Vidare var det mycket svårt att exakt avgöra var i testfältet fåglarna slog ner och ofta vilken typ av föda fåglarna bar i näbben. Observationerna skedd främst morgon och kväll då matningsaktiviteterna var som störst. Alla bon besöktes under matningsperioden av två observationslag om 1-3 personer. Av tabell 1 framgår vilka data som registrerades.

\section{RESULTAT}

Totalt registrerades 271 födsöksrundor under perioden 18 maj-7 juli. Resultatet är sammanställt i tabell 3. Mest besökt var Anderssons fält med två osådda rader per hjul för traktorn, med $12 \mathrm{~m}$ avstånd mellan traktorstråken. $41 \%$ av alla födosök gjordes i detta fält. Fåglar från alla bon deltog, förutom från boet vid Sörön. Honan där födosökte enbart i fältet på Bärstas mark, dit $18 \%$ av det totala antalet födosöksrundor förlades. Testfältet och de osådda kantzonerna besöktes oväntat sällan. Det finns en tendens att ortolansparven återvänder till samma ställe där den hämtade mat senast. Det kan då bli många födorundor i snabb takt. Totalt $70 \%$ av födosöken skedde på åkermark. Avstånden till platserna för födosök varierade mellan 47 och $114 \mathrm{~m}$ i medeltal.

Fåglar med föda från marken i näbben hade mörka markinsekter, vilket illustreras i appendix 3. Se också diskussionen.

\section{DISKUSSION}

\section{Olika häckningsförutsättningar}

Följande krav kan identifieras:

1. Sångplatser för hannen. Kraven är inte så stora. Det räcker med en buske eller stor sten eller kanske en ledningsstolpe. Ortolanerna häckar dock inte som sånglärkan ute på stora fält utan upphöjda sångplatser.

2. Lagom högt och tätt gräs för att dölja boet. Saknas naturlig gräsmark väntar ortolanen med häckningen till vårsäden blivit tillräckligt hög för att dölja boet.

3. Lämpliga födosökshabitat med bar jord blandat med skyddande vegetation i mitten av juni.
I tyska Bayern ansågs krav 2 vara svårast att uppfylla eftersom höstsäden hade växt sig hög och tät när ortolanen anlände i början av maj. Krav 3 var inget större problem då det fanns stora arealer med majs och solrosor sådda med större radavstånd. I Sverige däremot är krav 2 lätt att uppfylla medan krav 3 är svårt eftersom vi odlar mest stråsäd i ortolanområdena.

Ortolanstudier har pågått i Kvismaren hela perioden 2009-2017 och en kunskapsuppbyggnad har skett. Samtidigt har populationen stadigt minskat om man bortser från det sista året (2017). Bara den viktiga frågan om vad som karaktäriserar ett bra födsökshabitat har återstått att lösa. Detta är en nyckelfråga för att upprätthålla ortolanpopulationerna i Europa.

Information om den enda kända riktiga expansionen i Centraleuropa under senare decennier kommer från Wendland, Niedersachsen, där torrläggning av sanka betesmarker för att få större åkerarealer gjorde att ortolanen expanderade från nära o till 300 par (Deutsch 2007, Siegfried Spalik 2016, muntligen). Dikesgrävning, vegetationsröjning etc. gjorde att det skapades ett perfekt habitat för ortolan under flera år i början av 2000-talet.

En populationsökning skedde i Sörön ca 1980-2000 (appendix 1). Orsaken till detta var först svår att förstå eftersom ortolanen minskade i övriga områden i Kvismaren och på andra håll $\mathrm{i}$ landet. Troligen var orsaken de följdinvallningar och dikningsarbeten som skedde både väster och öster om Sörön under många år efter det att Kvismare kanal breddats från 15 till 30 m år 1970. Grävningsarbetena medförde att jordsträngar i perioder låg upplagda i stråk över fälten.

Den tyska ortolansparven passerar Frankrike och övervintrar i Västafrika (Bernardy 2016) på samma sätt som den svenska, och expansionen ägde rum trots andra påtalade problem med jakt i Frankrike och under övervintringen. Den enda kvarvarande viktiga faktor var alltså problemen med att finna lämpliga häckningsrevir där ovan nämnda krav kunde uppfyllas.

\section{Beskrivning av bra födosökshabitat}

Habitat där vi sett ortolansparven födosöka i Kvismaren kan delas upp enligt följande, i fallande ordning efter nyttjande (med andelen av det totala antalet födosök angiven inom parentes):

1. Osådda traktorspår (46,9\%): På senare år har det blivit allt mer vanligt att man lämnar i regel två rader 
osådda per hjul där traktorn sedan kan gå fram för att spruta och gödsla säden utan att köra ner växande sädesstrån (figur 4a). På de mindre fält som gränsar till ortolanernas häckningsdungar är det dock fortfarande inte så vanligt eftersom körningsmönstren bryts av dungarna på fälten.

En studie för att undersöka om en, två eller tre osådda rader (figur 2) var bäst misslyckade då det intill testfältet fanns ett fält med genomgånnde två osådda rader (Anderssons), teoretiskt ca $6 \%$ av arealen. I testfältet var andelen med två osådda rader bara $1 \%$ av arealen. Fyra av de fem ortolanparen födosökte främst i Anderssons fält.

2. Gles sådd och öppna fläckar i vanliga sädesfält (22,5\%): I vissa fält blir sådden gles eller gror inte sädeskornen som avsett (figur 4b). Detta var fallet i Bärstas fält intill Sörön 2017 (troligen beroende på inslag av mager sandjord). Då skapas mindre fläckar med öppen jord skyddade av den omgivande säden. Ett sådant fält utnyttjades av honan som häckade vid Sörön. Hon sågs inte födosöka på något annat fält. Normalt är dock fält av denna typ ovanliga i det storskaliga jordbrukslandskapet.

3. Utfodring med havre (11,4\%): För att ge ortolanerna bästa förutsättningar när de anlände till kallt och regnigt väder i början av maj lades havre ut på två platser. Under matningen av ungarna konstaterades att vissa honor i slutet av uppfödningen matade ungarna med havre.

4. Insekter i trädkronor av lövträd (6,3\%): Insektslarver som förekom i träddungarna sågs utnyttjas som föda. Vissa år förekommer massförökning av häggspinnmal och ekvecklare och då kan ortolanen gå över till att nästan enbart äta dessa larver. Sådana massförökningar förekommer bara var 5-10 år och är alltså inget att förlita sig på.

5. Osådda kantzoner (3,7\%): För att säkerställa öppen jord har osådda kantzoner på 2-3 m bredd rekommenderats i alla ortolanrevir. Sådana kantzoner fanns även i vårt försöksområde i Kvismaren 2017 (figur 5) men stråken utnyttjades dåligt, troligen eftersom två osådda rader utgjorde ett bättre födosökshabitat.
Andra positiva faktorer (9,2\%): Öppna diken och grävmassor är omtyckta av ortolanerna (sådana fanns dock inte i detta studieområde). I studieområdet sås i regel fälten senare än på omgivande lerhaltiga jordar som bär traktorerna tidigare på våren. Området är dessutom väldigt flackt, vilket gör att vattnet rinner av långsamt. I studieområdet dominerar vårsäd (mest vete) eftersom höstsäd riskerar att frysa upp. Vårsäden blir hög och tät senare under häckningssäsongen, vilket gynnar ortolanen.

\section{Kommentarer till födosöken}

Tillgången till gles säd, luckor, osådda traktorspår och kantzoner var viktiga för födosöket. Söröhonan födosökte enbart i Bärstas fält medan övriga fyra par föredrog Anderssons fält. Testfältet och kantzonerna utnyttjades ganska lite, de två lärkrutorna inte alls. Anderssons fält hade teoretiskt drygt $6 \%$ osådd yta medan testfältet hade hälften så mycket. Mycket talar för att två osådda rader var optimalt medan en och tre rader blev för tätt respektive för glest. I så fall betyder det att $6 \%$ ska jämföras med $1 \%$, vilket kan förklara ortolanernas förkärlek för Anderssons fält. Att kantzoner besöktes så sällan kan förklaras med att det fanns bättre alternativ på platsen. Troligen är det dock lämpligt att skapa osådda kantzoner eftersom det utgör en försäkran mot total igenväxning.

Avståndet till födosöksplatserna var måttligt, även om Lindåsahonan flög förbi fält utan osådda rader för att födosöka på Anderssons fält. Födosök på längre avstånd än $200 \mathrm{~m}$ var ovanligt och det maximala födosöksavståndet som noterades var $250 \mathrm{~m}$.

\section{SLUTSATSER}

Denna studie indikerar starkt att ortolansparven är beroende av mörka markinsekter som den plockar på bar mark i åkerfälten. Dessa jordytor bör vara skyddade för t.ex. rovfåglar av omgivande stående vegetation, mestadels sädesplantor. De bästa platserna var i traktorstråk med två osådda rader per hjulspår, teoretiskt $0,37 \mathrm{~m}$ brett, i ett fält med bara $12 \mathrm{~m}$ mellan traktorstråken. Lägre och glesare säd med bara fläckar var också ett utnyttjat habitat. Ungefär $70 \%$ av de observerade födosöksrundorna berörde tillsammans sådana platser. Möjligen är ändå sådana fält inte tillräckligt goda födosökshabitat för att ortolansparven ska upprätthålla sin populationsstorlek. Bara vid Sörön i samband med 
dikningsföretag (då jorden rördes om extra mycket och låg blottad under längre perioder) har vi noterat en populationsökning.

\section{SKÖTSELREKOMMENDATIONER}

I områden med ortolansparv rekommenderar vi att följande krav uppfylls i alla ortolanrevir på jordbruksmark i Sverige:

- Garantera att sädesfälten i närheten av ortolanrevir får två osådda rader för varje traktorhjul. Om markägaren inte har någon såddmaskin som kan göra sådana osådda spår, låt en entreprenör så åtminstone fyra hektar på detta sätt. Bäst är $12 \mathrm{~m}$ mellan körstråken men om 24 m utnyttjas bör fältets areal med spår fördubblas. Både höst- och vårsäd är lämpliga grödor.
- Små trädholmar gillas av ortolanerna. Underväxten bör röjas där och större träd bör kvarlämnas på ca $10 \mathrm{~m}$ avstånd.

- Osådda kantzoner längs fälten rekommenderas för att garantera att det finns tillräckligt med öppen jord. En kilometer per par är en lämplig sträcka. Sådana kantzoner är dessutom i enlighet med EUs rekommendationer.

\section{Varning}

Om vallar för ensilageskörd finns i ortolanområdet är risken stor att paret bygger sitt bo där. Ett sådant riskområde bör avgränsas och slåttras först $\mathrm{i}$ juli.

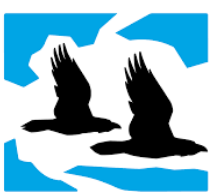

Birdlife Sverige

Ornis Svecica (ISSN 2003-2633) is an open access, peer-reviewed scientific journal published in English and Swedish by BirdLife Sweden. It covers all aspects of ornithology, and welcomes contributions from scientists as well as non-professional ornithologists. Accepted articles are published at no charge to the authors. Read papers or make a submission at os.birdlife.se.

Ornis Svecica (ISSN 2003-2633) är en fritt tillgänglig granskad vetenskaplig tidskrift som ges ut på svenska och engelska av BirdLife Sverige. Den täcker ornitologins alla områden och välkomnar bidrag från såväl forskare som icke-professionella ornitologer. Accepterade uppsatser publiceras utan kostnad för författarna. Läs uppsatser eller skicka in ditt bidrag på os.birdlife.se. 


\section{Appendix 1. Census data from Sörön, Kvismaren}

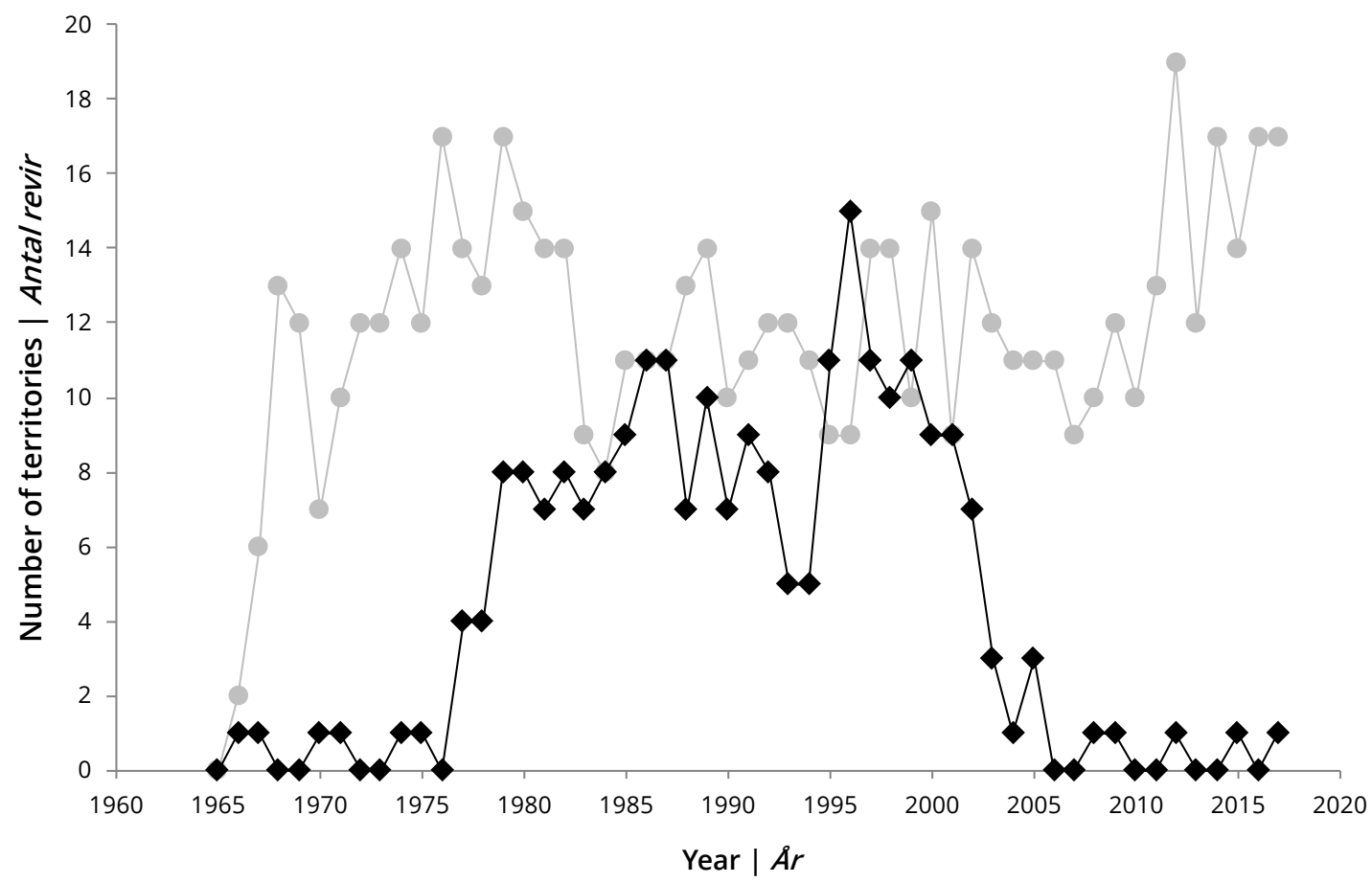

Number of territories (singing males) of Yellowhammer Emberiza citrinella (grey circles) and Ortolan Bunting E. hortulana (black diamonds) at Sörön, Kvismaren, 1965-2017 extracted from census data collected at Kvismare Bird Observatory. The area of the deciduous forest Sörön is some 22 hectares. The northern part of Sörön is visible in Figure 1 and Appendix 2.

Antal revir (sjungande hannar) av gulsparv Emberiza citrinella (grå cirklar) och ortolansparv E. hortulana (svarta fyrkanter) i Sörön, Kvismaren, 1965-2017, sammanställt från inventeringsdata insamlade vid Kvismare fågelstation. Ytan på lövskogen Sörön är ca 22 hektar. Norra delen av Sörön kan ses i figur 1 och appendix 2. 


\section{Appendix 2. Example field map}

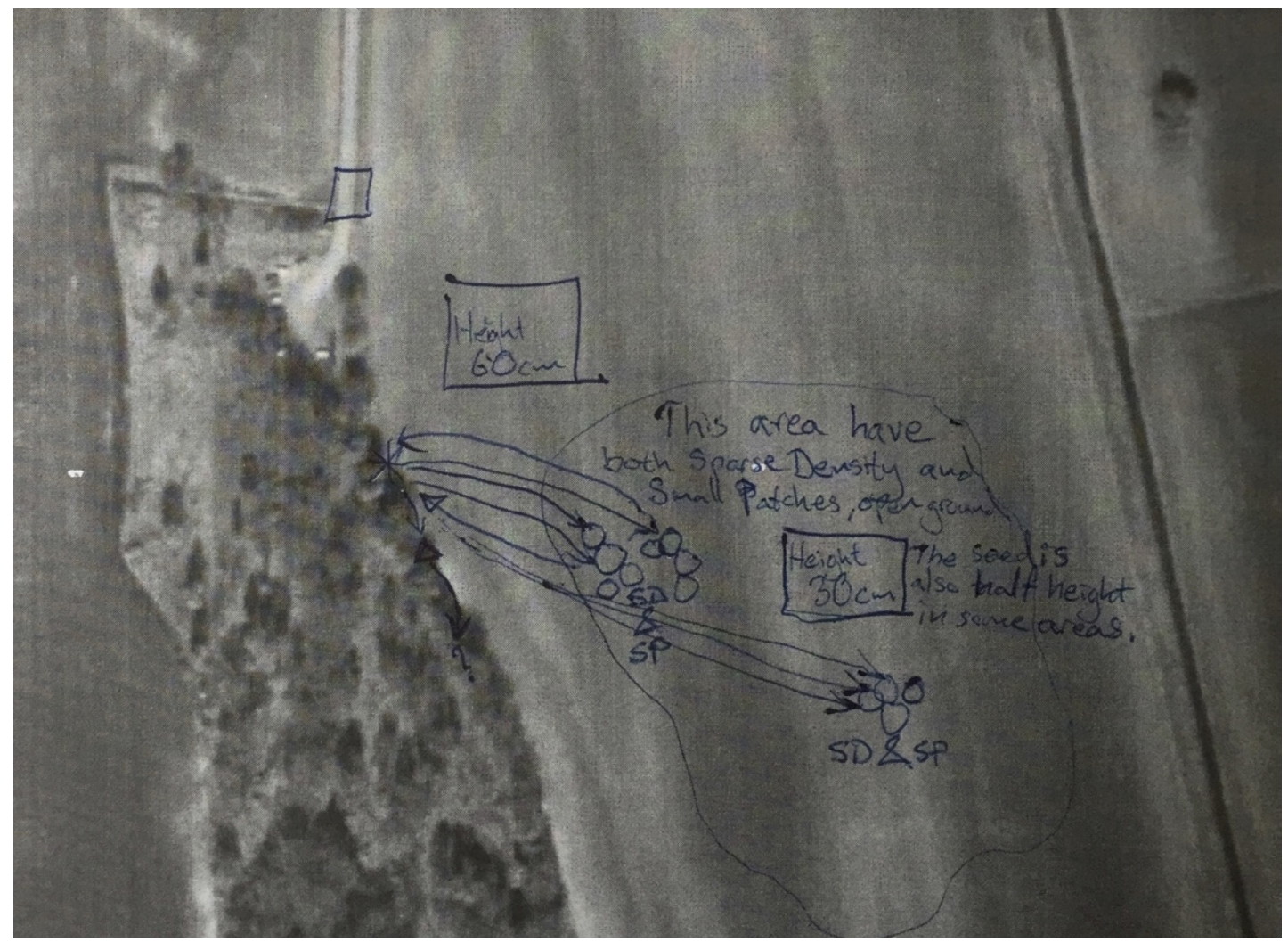

Work paper for field notes with part of Google Maps as background; showing the northern tip of Sörön. Abbreviations used in the field work are also present: SP (Small [unsown] Patches) and SD (Sparce Dencity [of the crop]). The height and density of the crop varied a lot at that time (20 June) in this particular field. North of the foraging area the height was $0.6 \mathrm{~m}$ compared to $0.3 \mathrm{~m}$ further to the SE. There were also several small patches and sparse areas (probably because of sand elements in the soil). See also Figure 4b.

Arbetspapper från karta i Google Maps av norra spetsen av Sörön. Förkortningarna som användes i fält var SP (små osådda fläckar) och SD (gles täthet på säden). Norr om födosöksområdet var säden 0,6 m jämfört med 0,3 m längre söderut. Där fanns också osådda luckor och gles säd, troligen på grund av inslag av sand i jorden. Se figur $4 b$. 


\section{Appendix 3. Photographic documentation of prey}
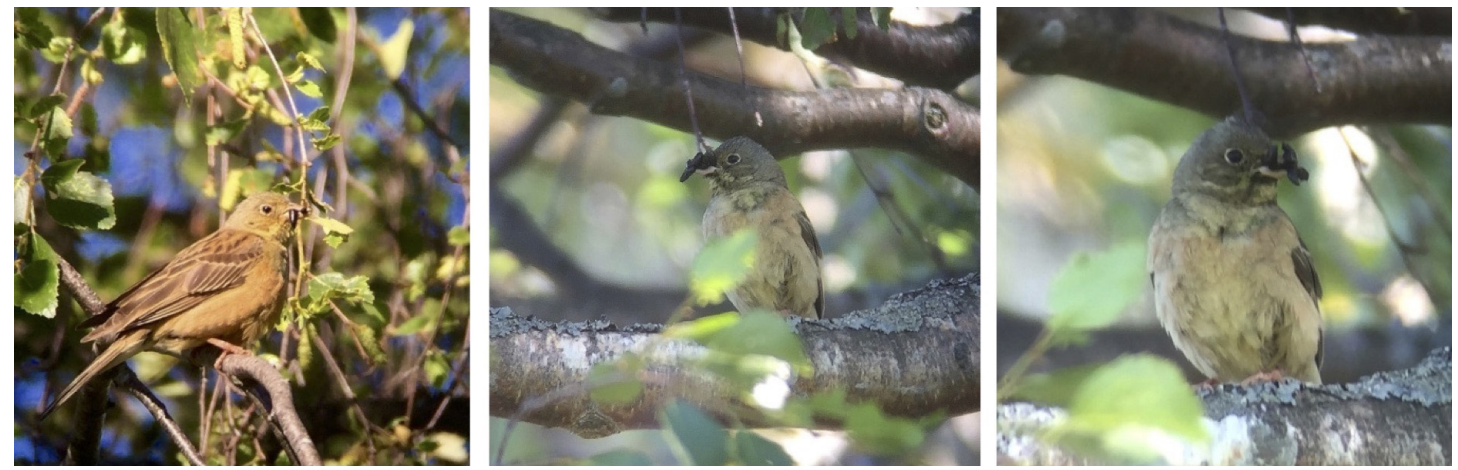

Two Ortolan Buntings Emberiza hortunala (middle and right photo of the same individual) with dark invertebrates in their beaks, collected from the ground within spring wheat crops. Photos: Magnus Persson.

Två ortolansparvar E. hortulana (fotot i mitten och till höger av samma individ) med mörka ryggradlösa djur i näbbarna hämtade från marken i vårsädesfält. Foton: Magnus Persson. 